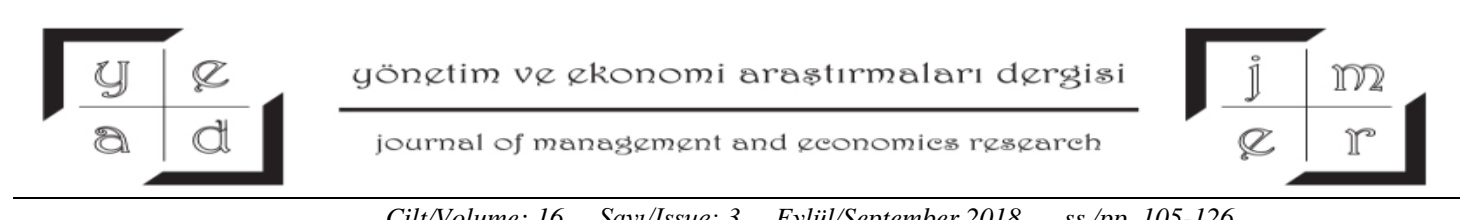

Cilt/Volume: $16 \quad$ Sayl/Issue: $3 \quad$ Eylül/September $2018 \quad$ ss./pp. 105-126

H. Derya Doi: http://dx.doi.org/10.11611/yead.444223

\title{
HUKUK EKONOMİ İŞBİRLİĞİ: FRANZ BÖHM
}

\section{Dr. Öğr. Üyesi Hülya DERYA*}

\begin{abstract}
ÖZET
Bu çalışmanın amacı, 19.yüzyılda Almanya'da hukukun yetersizliği, kartellerin fazlalaşması ve bilimin geriye itilmesi sorunsalına çözüm olarak Freiburg Okulu Ordo-liberalizm temsilcisi Franz Böhm'ün ekonominin bir anayasaya ihtiyacı olduğu yöndeki düşüncelerini incelemektir. Dönemin iktisadi ve sosyal yapısl; Tarihçi Hareket, Alman Tarihçi Okul ve Nasyonel Sosyalizm etkileşiminden oluşmuştur. Bu dönemin karakteristik yapısı, hukuksuzluğun, kartel ve monopollerin artmasıdır. Franz Böhm, ekonomik ve sosyal özgürlü̈̆̈̈n gelişimi için ekonominin anayasal çerçeveye alınmasını savunmuş ve tekel sorununu gözetim dairelerinin kurulması ile çözülebileceği görüşlerini dillendirmiştir. Nasyonel Sosyalizim döneminin sona ermesi ile Almanya’nın kurumsal yapısı Franz Böhm'ün katklları ile şekillenmeye başlamıştır. Bu çalışmada, Franz Böhm ile başlayan hukukun ekonomik işleyiş üzerinde meydana getirdiği etkiler değerlendirilecektir.
\end{abstract}

Anahtar Kelimeler: F.Böhm, Nasyonal Sosyalizm, Anayasal Ekonomi, Ordoliberalizm

Jel Kodu: B15, B25, B30.

\section{LEGAL ECONOMIC COOPERATION: FRANZ BÖHM}

\begin{abstract}
The aim of this study is to examine the ideas of Franz Böhm, the representative of Freiburg School Ordo-liberalism. He advocates that the economy needs a constitution as a solution to the problemsin the inadequacyof the law in the 19th century Germany, the excess number of monopolies, andlack of importance of the science. The historical and social structure of the era was formed by Historian Movement, the German History School and National Socialism. The characteristic structure of this period is the rise of illegal situations and monopolies.Franz Böhm asserts that in order to improve economic and social liberalism, it is necessary to locate economy into constitutional framework. Also, he advocates that the problem of monopoles can be solved by forming inspection circles. After the era
\end{abstract}

\footnotetext{
* Kilis 7 Aralık Üniversitesi, İ.İ.B.F., Siyaset Bilimi ve Kamu Yönetimi Bölümü,79000, Kilis, Türkiye e-mail: $\underline{\text { hulyaderya11@gmail.com }}$
} 
of National Socialism, the institutional structure of Germany has been shaped by the contribution of Franz Bohm.This study assesses the effect of the law on economic operations, started by Franz Böhm.

Keywords: F.Böhm, National Socialism, Constitutional Economy, Ordoliberalism

Jel Codes: B15, B25, B30.

\section{GİRIŞ}

19. yy’ın en azından ilk yarısı İngiltere'de Smith ve Ricardo özelinde klasik ekonomik politiğin şaşalı günleri iken Almanya bu ekole çok fazla kapılmamışır. Bunun temel sebebi Almanya'nın İngiltere'den ekonomik anlamda geride olmasıdır ${ }^{1}$.Almanya'da 19.yüzyılda gerek tarihçi hareket ve gerekse Romantizm akımı, hukuk ve bilimin arka plana itilmesine aracılık etmiştir. Tarihçi hareket beraberinde Alman Tarihçi Okulu'un gelişmesini sağlamıştır. Bu ekolün Pragmatik ve korumacı politika düşünceleri, Bismarck ${ }^{2}$ tarafından ülkenin kalkınmasında kullanılmaya çalışılmıştır. Rölativizm ve kadercilik gelişmiş bu, hukukçunun olaylar karşısındaki konumunu belirlemiştir. Güç grupları hukuku şekillendiren ve hatta belirleyen bir unsur olmuştur. Bu söylenenlerin en belirgin olduğu noktalardan biri karteller ve monopollerin 1897 yılında yasayla meşru hale getirilmesidir. Alman Tarihçi Okulu'nun etkisinin azaldığı 1933 yılında Nasyonel Sosyalistlerin (Nazilerin) işbaşına geçmesiyle hukuk yine arka plana itilmiştir. Almanya' da pek çok bilim adamı ve ekonomist Nasyonel Sosyalistlere muhalif olmaları sebebi ile çalışmalarından ve görevlerinden uzaklaştırılmıştır. Nasyonel Sosyalistlerden sonra Almanya' da hukuk ve bilimin egemenliğine geri dönmek için liberalizm kökenli ordoliberalizm bir çıkış noktası olarak kabul görmüştür. Ordoliberalizm Freiburg Okulu çatısı altında Nazi döneminde Walter Eucken,Franz Böhm,Wilhelm Röpke,Grossmann-Doerth ve Müller Armack’ın bilimsel çalışmalarına dayanmaktadır ve "Ordo" düzen demektir. Yani anayasal ekonomidir. Hukukçu Böhm, ordoliberal anlayışla ekonomiyi farklı yollardan hukuk diline çevirmiştir. Monopol ve kartellerle mücadele ederek rekabet ekonomisinin yasayla kontrol altına alınmasına uğraşmıştır. Farklı çıkar gruplarını eşitlemeye çalışmıştır.

Bu çalışmada; Almanya'nın 19.yüzyıl Böhm'ün yaşadığı dönemine kısaca baktıktan sonra Böhm'ün ordoliberalizmi algılayışı, Smith'le farklılıkları ve benzerlikleri kısaca açıklanacaktır. Böhm'ün kurumsallaşmaya giden süreçte anayasal hukuk, özel hukuk kavramlarının ekonomi ile ilişkisi sonrasında demokrasi ve rekabete bakışı değerlendirilecektir.

\section{BÖHM'ÜN YAŞADIĞI DÖNEM}

Britanya klasiğinin Alman versiyonunu anlamak için, Almanya'nın 19. Yy. İngiltere'ye oranla ekonomik geriliğini göz önüne almak gerekmektedir. Klasik iktisadi düşüncenin çok yoğun olarak kabul gördüğü kısa bir dönemin ardından, Almanya'da tarihi bir rüzgâr esmeye başlamıştır. Herder, Goethe,

\footnotetext{
${ }^{1}$ Almanya biran önce İngiltere'nin kalkınmışlık seviyesine ulaşabilmek için farklı yollar arayışına girmiştir.

${ }^{2}$ Bismarck;19.yüzyılda Almanya'nın şansölyesi yani başbakanıdır.
} 
Grimm, Schlegel, Savigny, Hegel ve Ranke gibi isimlerin tarihçi hareketi derinden ve bilinçaltına inecek şekilde toplumu etkilemiştir. Tarihçiler, insani kuvvetlerin genel gözleminin yerini, bireyselleştiren gözlemin alması sonucu ortaya çıkmışlardır. Tarihçi hareketin etkisi ile ortaya çıkan, Alman Tarihçi Okulu; devlet, toplum ve iktisat üzerine olan mütalaasını, kısmen klasik öğretinin bireysel görüşüne ve soyut indirgemeci metoduna tezat oluşturacak şekilde, soyut ile zaman üstü iktisadi kanunların ret edilmesi sonucu geliştirmiştir. Böylece iktisadi yansımaların bilgilenmesini, onun tarihsel oluşumu üzerine kurgulamak istemiş ve bunun sonucu olarak tüm aceleye getirilmiş genelleştirmeleri ret etmiştir. Çünkü tüm ampirik gerçeklikler, toplumsal bağlamda araştırılmalı ve tanımlanmalıydı. Alman Tarihçi Okul için iktisadi yansımalar, tarihsel gelişimlerin bir ürünüdür. Hukuku pragmatik politikalarıyla istedikleri gibi şekillendirerek ulusun kalkınmasını sağlamaya çalışışlardır. Realiteyi ve hayatın kendisini yakalama gayreti içerisinde, tüm insani kurumların ve fikirlerin değişebilir oluşuna payende verilmiştir. Gelişim düşüncesi bu akımı çok etkilemiştir. Hukukun ve ekonominin tarihçi perspektifle değerlendirilmesinin, bilimin ufkunu olabildiğince genişlettiğini göstermeye çalışmışlardır. Hukuk düşüncesi zayıflatılarak, itibarı yok etmiştir. Savigny’e göre, hukuk oluşumunu sağlayan içsel ve derin kuvvetlerse, 19. yüzyılda karakterlerini olabildiğince değiştirmiştir (Savigny,1814:187-202).Büyük çaplı ekonomik güç grupları, hukuku tek taraflı şekillendirmişlerdir. Ekonominin önemli alanını kapsayan borçlar hukuku devre dışı bırakılmıştır. Hukuk bilimi ve yargıysa, temel istisnalar dışında bu tehlikeli gelişmeye sessiz kalmıştır. Bu dönemdeki ekonomik gerçekler, hukukçuların gözünde değişmez gerçek olarak algılanarak, hukuk buna göre uydurulmuştur. Tarihçi hareket, Romantizm ve Tarihçi Okul, hukuk ile bilime yönelik sistem inancını yıkmıştır.

Kartellerin, Alman Tarihçi Okul döneminde yasayla meşruiyet kazanması ile piyasa kurallarına dayalı ticari düzenlemeler ve faaliyetler yürütülememiştir. Yine aynı şekilde hisse senedi kanunu da bu türdendir, çünkü burada egemen güçler adeta devletin zorlayıcı hukukunu etkisiz hale getirmeyi başarmaktadır. Bismarck döneminde; monopolleşme ile ilgili ekonominin bütün düzenini bozup bozmadığına yönelik sorulan sorular, ciddi biçimde incelenmemiş̧tir. Eğer bu yapılsaydı, o zaman ileride ortaya çıkabilecek ağır hasarlara karşı tedbirler alınabilirdi. Böylelikle bilim vazifesini yerine getirmiş olurdu. Bu durumda Almanya'da çok sayıda monopolün kurulması ve monopol problemiyle ilgili bilimsel çalışmanın çok az olmaması şaşırtıcı olmamalıdır. Almanya' da bu şekilde hem hukuk hem de ekonomi bilimi manevi ve ahlaki bir güç olmaktan çıkmıştır. Ekonomik çıkar güçleriyse bundan faydalanmıştır. 1.Dünya savaşından önce bile tarihçi ekonomik anlayışa karşı genç akademisyenlerin (özellikle tarih üzerinde uzmanlaşmış olanlar) başlattığı bir karşı harekete tanık olunabilmektedir (Rieter, 2002:155). Bu hareket Alman Tarihçi Okulu'n 1917 gerilemesinin ardından önemli bir dinamik kazanmaktadır (Janssen,2000:35-40). Böylece tekrardan klasik düşünce mirasına yönelme gerçekleşir, ama bu hareket aynı zamanda kendisine karşı duran düşüncenin de büyük etkisi altındadır. Nasyonel Sosyalistlerin güçlenmesi klasik düşünceyi bastırmıştır. 
Alman Tarihçi Okul'dan sonra Nasyonel Sosyalistler 1933 yılında başa geçmiştir. Nasyonel Sosyalistlerin iktidara gelmesi ile hukuk yine arka plana itilerek, partileri ve sendikalarıkapatılmıştır. Hitler aldığı tedbirlerle işsizliği önemli ölçüde azaltarak, "ekonomik mucize” algısı yaratmış gözükse de, bu bir balondu ve büyümeye devam etmek için savaş kaçınılmaz hale gelmiştir. 2. Dünya savaşından sonra iseAlmanya'da pek çok bilim adamı gibi Böhm'ün Nasyonel Sosyalistlere muhalif görüşleri sebebi ile çalışmalarına ve üniversitedeki görevlerine engel olunmuştur. Böhm, Nazi baskısı sonucu profesörlük yolunun kapandığını görünce, Jens Peter Jessen'in yönettiği Alman hukuk akademisine angaje olmuştur. Burada ülkenin ekonomik olaylarıyla ilgili gelişmeleri değerlendirmektedir. Aynı zamanda Nasyonel Sosyalist diktoryasına karşı bir örgütlenme vardır. Direniş örgütü olarak adlandırılan bu grubun içerisinde Eucken, Böhm ve Lampe'de vardır. Bu dönemde Hitler tarafından Böhm, Eucken,

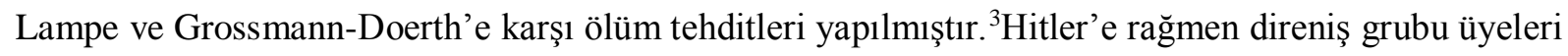
yazılarını yazmaya devam etmiştir. Direniş grubunun yazıları zamanla Gestapo'nun dikkatini çekmektedir. Direniş grubu orijinal yazıları Freiburg profesörlerinden olan Gerhasrd Ritter tarafindan kara ormanlar bölgesinde saklanmıştır. Yazıların kopyaları Gestapo'nun eline geçmeye başlayınca Böhm zor duruma düşmüştür (Nils,2005:449 -452).Gestapo 1944 sonbaharına kadar Freiburg direniş örgütünün pek çok tanıdık simasını tutuklamıştır. ${ }^{4}$ Bunların arasında Profesör Dietze ve Lampe'de vardır. Gestapo bir sorgu sırasında “papaz Böhm'ün bu gruba dâhil olduğunu” öğrenmektedir. İște bu yanılgı Böhm'ün hayatını kurtarır, çünkü Gestapo bütün aramalarını "Papaz Böhm” üzerine odaklamaktadır. Muhtemelen burada Franz ismi Almanca Pfarrer olarak yanlış anlaşılmıştır(Buchstab, 1990:25).

Nasyonel Sosyalist dönemde Freiburg Okulu'nun kurucusu Eucken etrafında direniş grubu toplanmaya başlamış ve "Almanya içerisinde bilimsel temasları" sıklaştırmıştır. Böhm sürece düşünsel anlamda destek olarak, Eucken'le beraber 1948 yılında “Ordo”(Düzen) isimli dergiyi çıkarmaktadır. Böhm ve Freiburg Okulu'nun düşünceleri birleşerek, Alman anayasasını şekillendirecek çerçeveyi yazıya dökmüşlerdir. Onun bu net duruşu, bilimsel basireti, Nazi rejimine karşı direnişi federal Almanya cumhurbaşkanlığı aday statüsüne taşımaktadır. Böhm her dönemde hukuku savunmaktadır. Liberalizm taraftarı olarak ekonominin bir anayasaya ihtiyacı olduğunu tüm eserlerinde görmek mümkündür (Hollerbach, 2007: 299) ${ }^{5}$.

\section{NEOLİBERALIZMIN ORDOLİBERALİZME EVRILMESİ}

Neoliberal öğreti, 1920'li ve 1930'lu yıllarda ortaya çıkan ekonomik ve sosyal duruma özellikle dünya ticaret krizine yönelik bir cevap olarak görülmelidir. Her ne kadar klasik liberalizm saf formu itibarıyla hiç uygulanmadıysa da, 1929 dünya ekonomik krizinin geniş etkileri (işsizlik, fakirlik vs.)

\footnotetext{
${ }^{3}$ Böhm, 1933 yılından itibaren Hitler'in Yahudi soykırımına karşı çıkarak, özgürlüğü en önemli değer olarak görmüştür (Hansen,2009:140).

${ }^{4}$ Gestapo, Hitler Almanyasının gizli siyasal polis örgütü.

${ }^{5}$ Böhm Alman anayası ve kartel yasalarının oluşumunda katkı sağlamıştır.
} 
liberalizmin hatası olarak görülmektedir. Çünkü Bırakınız-yapsınlar-bırakınız geçsinler liberalizmi optimal sonuçların ortaya çıkmasını sağlayamamaktadır ${ }^{6}$. Devletin aşırı pasif rolü ve bununla ortaya çıkan kartellerin rekabet kısıtlamaları, ekonomik gelişim için geriletici bir unsur olmaktadır. Bunun sonunda Almanya' da liberalizm arka plana itilmektedir (Reinhard,1969:47). Aynı şekilde sosyalist plan ekonomisine dayalı yeni bir meydan okuyuşun belirmesi de, liberalizmin yeniden değerlendirilmesini zorunlu kılmaktadır (Hayek, 1983:12) ${ }^{7}$. Neo-liberalizm yaklaşımı zamanla farklı yönlere doğru gelişim göstermektedir. Bu farklı yönler kısmen bazı yazar/okullara addedilse bile, her zaman sınıflandırma veya ayrıştırma konusunda bilim çevrelerinde bir konsensüsün oluşmadığını görebilmekteyiz. Ayrıca okulların liberalizmin bir formu olarak değerlendirilmeleri veya bunların kendilerine özgü bir iktisadi anlayış taşıyıp taşımadıkları tartışma konusu olmuştur. Örneğin Jan Hegner’e göre bu okullar arasındaki fark, sadece bunların devletin ekonomik olaylara müdahale şiddetini farklı yorumlamalarında yatmaktadır (Hegner, 2000:7).

Almanya'da neoliberaller Freiburg Okulu çevresinde ordoliberalizm adı altında bir araya gelmektedirler. Ordoliberal teori oluşumunu, Eucken, Böhm, Rüstow, Röpke ve Müller-Armack'ın 1932/33 döneminde kaleme aldıkları eserler belirleyici nitelikte olmaktadır. Bu yazarlar birbirlerinden bağımsız bir şekilde “1920'li yılların krizini” analiz etmeye çalışarak, yeni liberalizmin ilk algısını oluşturmuşlardır. Freiburg Okulu Nazi diktatoryası altında gizli gizli çalışmalarına devam edebilmiştir. Oysa Marksistler ve Keynes 'çiler ülkeyi terk etmek zorunda kalmıştır (Jansen,2000:35-40). Burada öncelikli olarak liberal duruşun revize edilmesi gerekmektedir. Devlet kurum kimliğiyle, piyasa ekonomisi prensiplerinin yerleştirilmesi amacıyla bir enstrüman olarak düşünülmektedir. Kapitalist ekonominin kriz nedeniyle çökmediği ortaya konulmaya çalışılmaktadır. Hedef, özgür piyasa ekonomisinin daha etkin olmasını sağlayacak yeni bir ideolojik meşruiyet oluşturmaktır. (Wetzel,1987 :3).Eucken, Böhm ve Großmann-Doerth Freiburg Okulunu "stratejik ve geniş ufuklu bir bakış açısıyla" kurmuşlardır. Bir araya geldikten kısa bir süre sonra yazı dizisi “Ekonominin Düzeni” (Ordnung der Wirtschaft'1) çıkarttılar ve ekonomi-hukuk-devletin monografik olarak araştırılacağı bir plan ortaya koydular. Böhm burada "Ekonominin düzeninin tarihsel bir görev ve hukuksal bir yapı" üstlenmesi gerektiğini savunmaktadır.Bunu kuruluş manifestosu sayarak Eucken, Böhm ve Großmann-Doerth'in imzalamaktadır. "Bizim Ödevimiz" (Unsere Aufgabe) isimli manifesto, hukuk ve ekonomi bilimi için yeni bir araştırma programı niteliğindedir. ${ }^{8}$ Almanya geçmişinde yaşadığı hukukun yetersizliği ve kartellerin fazlalaşması ekonominin bir anayasaya ihtiyacı olduğunu iktisatçılara ve hukukçulara

\footnotetext{
${ }^{6} 1929$ krizi öncesinde savaşın getirmiş olduğu içe kapanan ekonomiler ve dünya ticaret hacmindeki daralmanın etkisi vardır.

${ }^{7}$ Eren (2015) Hayek'in dönemin genel yaklaşımına karşıt bir şekildeliberalizm ve piyasa savunuısunu benzer bir temelde ele almiştır.

825 Nisan 1945 yılında Nazi rejiminin yıkılmasının hemen ardından Franz Böhm Freiburg üniversitesinde öğretim üyesi oldu. Bu noktada eski rektör Martin Heidegger'i Fransız işgal güçlerine şikâyet etti. Böhm bir süre sonra 1 Kasım 1945 tarihinde Frankfurt'a Hessen eyaleti Kültür Bakanı olarak geçti ve CDU partisine katıldı Fakat daha sonra "klasik eğitimi” desteklediği için Amerikan işgal gücüyle arası açıldı ve Frankfurt üniversitesi rektörlüğüne geçti ve hayatı boyunca buraya sadık kald1(Janssen,2000:56).
} 
hissettirmektedir. Freiburg Okulu ordo-liberalizmin temsilcisi olarak değerlendirilmekte ve bunun yaklaşımları neo-liberalizme yakın bulunmaktadır.

Ordoliberalizmin temel konusu ekonomik kurallar ve iktisadi düzendir. Ekonomik düzenle devlet yapısı arasındaki karşılıklı bağımlılığa işaret edilmektedir (Eucken,1990:130). "Ekonominin düzeni”" demek, hem ekonominin bütününün hem de toplumun kaldırabileceği düzeni vermek demektir: "Ekonomik anayasa, milli ekonomik hayatın üzerindeki politik kararlar bütünü olarak anlaşılmalıdır."” Ekonominin sınırlarının çerçevesi yasayla belirlenmektedir. Bu düşüncenin merkezinde, toplum ekonomik hayatının düzenlenmesinde bilinçli olarak yerleştirilmiş bir ekonomik kurallar bütünü (anayasa) vardır. Rekabet ise bu noktada önemli düzenleyici bir prensiptir, aynı şekilde düzen içerisinde yer almaktadır (Böhm, Eucken, Doerth,1937: 101). Ordoliberalizmin temsilcileri liberal piyasa ekonomisinin suni bir yapı olduğunu ve eğer regülasyona tabi tutulmazsa, kendini ortadan kaldırmaya eğilimli olduğunu dillendirmektedirler. Bu görüşe, rekabetin sonuçlarından hareketle ulaşmışlardır. Rekabet liberalizmde varsayıldığı gibi piyasayı işleyişine dayanan bir yapının tersine temel olarak ekonomide monopollerin oluşmasına ve orta boy-küçük aktörlerin piyasadan itilmesine yol açan bir süreç yaratmaktadır. En nihayetinde bu durum piyasanın bütünüyle birkaç büyük aktörün denetimine gireceği anlamına gelmektedir. Böylece serbest rekabet kendi kendisini ortadan kaldırmış olacaktır. Ayrıca böyle bir gelişmenin sonunda, ekonomi içerisindeki kamusal olmayan aktörlerin politik kararlar üzerinde etkili olması beklenmektedir. Bu yüzden ordoliberalizm devletin ekonomiye müdahalesini belirgin biçimde tanımlamaktadır. $\mathrm{Bu}$ müdahale çerçeve koşullarının oluşturulması biçiminde olmaktadır. Çerçeve yasa kartel kanununuda kapsamaktadır. Devlet ekonomik faaliyetin yürütüldüğü alanı etkilemelidir, ama ekonomik süreci bizatihi kendisi yürütmemelidir (Eucken,1951:72) ifadeleri ile formların devlet tarafindan belirlenmesine evet; ekonomik sürecin devlet tarafindan planlanmasına hayır. Fonksiyonel devlet anlayışını benimsemişlerdir. Aşırı bürokratikleşmeyi engellemek için piyasaya büyük hareket alanı bırakılmıştır. ${ }^{10}$

Freiburg İktisat Okulu; Tarihçi Okulun ve Nazi döneminin sosyolojiyi ve tarihi ekonomi-politik içerisine entegre etme denemesinin, problemlerin analizini kolaylaştırmak yerine zorlaştırdığı gerçeğini gözler önüne sermektedir. Buradan yola çıkarak genel bir değerlendirmede bulunmak için, öncelikle kısmi düzen analizinin gerçekleştirilmek zorunluluğunu ve katı bir bilimsel işbölümünün gereklerini savundular. Hoılistik yaklaşım, yani toplumsal bütünün bilgilenmesine ulaşmak için kısmi düzenlerin bilgisine sahip olma fikri, Freiburg İktisat Okulu ve Smith'in ortak yönünü oluşturmaktadır. Smith'in güç konusuna yaklaşımı ise, Hobbes'in kötü senaryosuna pozitif bir yanıttır. ${ }^{11}$ (Hobbes,1651:67). Smith'in, ana argümanı "kuvvetli bir devletin gereksiz olduğu” şeklindedir.

\footnotetext{
${ }^{10}$ Ordoliberalizmde ,zayıf müdahale devletinin yerine "kuvvetli devlet" getirilmek ve bu şekilde işlerliği olan bir rekabet ekonomisi oluşturulmak isteniyordu. Ordoliberalizim bu dönemde kendi kimliğini ve dinamiğini, daha ziyade Marksizm'e ve Keynes'çiliğe karşı konumlanmakla kazanmıştır(Eucken,1990:78).

${ }^{11}$ Hobbes devletin mutlaka gerekli olduğu görüşündedir.
} 
Çünkü bireyler arasındaki kendiliğinden etkileşim istikrarlı bir düzen için gerekli koşulları oluşturuyordu. Hiçbir şekilde ekonomik güç konusunda kör değildi ve bu noktada ekonomik egemenliğin ortaya çıkmasını önlemek için rekabetin varlığının en iyi çözüm olduğunu düşünmektedir. Freiburg İktisat Okulu'nun çıkış noktasıysa buna karşın “negatif sorudur.” Ekonomik gücün veya egemenliğin oluşumu nasıl engellenebileceği ile ilgilenmişlerdir. Almanya geçmişteki tecrübesinden etkilenmiş bir şekilde, bireyler arasındaki kendiliğinden etkileşimin ister istemez iktisadiliğin egemenleşeceği endişesini taşıyordu ve bunun daha sonra politik sisteme intikal edeceğini düşünüyorlardı. Öyleyse Smith için rekabet, toplum içerisindeki bireylerin kendiliğinden ve barışçıl işbirliğinin temelini oluşturmaktadır. Bireylerin çıkarından yola çıkan Smith toplumunda çıkarına olacağını savunur. Egemenlik oluşumunu engellemesiyse ancak ikincil bir özellik olarak kabul edilmektedir. Eğer bireylerin kendiliğinden etkileşimi pek de arzulanmayan bir toplam "düzene” yol açarsa, o zaman bu noktada düzeni sağlamak için bireylerin üzerinde duran kuvvetli ve nötr bir devlete gereksinim vardir.

Klasik liberaller, neo ve ordoliberaller arasındaki en büyük benzerlik, onların bütün ekstrem müdahaleleri (yani hem devlet müdahalelerini hem de mutlak liberalizmi) ret etmeleri oluşturmaktadır(Grossekettler,1997:6-19,79).Özgürlüğün azamileştirmesi hedefi, ancak toplumsal refah hedefinin yeterince değerlendirilmesinin ardından bir anlam taşımaktadır. İktisadi düzen üzerine farklılıklar ise, oyun kurallarının şekillenmesi bazında tespit edilebilmektedir. Yani "iyi bir neden" olarak kabul edilen varsayımın, anarşist idealden tam olarak hangi şekilde uzaklaştığı üzerinde durulmaktadır. Ordo-liberalizm, hukuk devleti ve düzen anlayışıyla eski liberalizm ve sosyal liberalizm arasında bir ara form oluşturmaktadır. Freiburg Okulunun politik hedefi, hukuk ve ekonomi biliminin "kamu hayatındaki önder rolünü” geri kazanmasını sağlamak ve "hukuk ve ekonomi-politik kararlar" üzerindeki etkisini artırmaktır. Aynı zamanda politikanın nesnelleştirilmesi olarak anlaşılabilmektedir. Bu sonuçta ancak bilimin ideolojiden arındırılmasıyla mümkündür.

Meseleye bilimsel olarak yaklaşmak için, ekonominin temel düzenleyici prensipleri önem kazanmaktadır. Ekonominin sadece yasal çerçeveye alınması yeterli gelmemekte bunu destekleyen düzenleyici prensiplere de ihtiyaç vardır. Düzenleyici prensiplerin oluşturulması, esasında ekonominin düzeninin bir iktisat kuralları bütününe bağlı olduğunu göstermekten ileri gitmez. Tüm somut hukuki ve ekonomik sorunlar mutlaka ekonomi kuralları içerisinde değerlendirilmelidir." ${ }^{12} \mathrm{Bu}$ türden bir düzen, her türlü ayrıcalık ve egemenlik arayışlarına karşı koyabilir, grupların çıkarlarına hizmet etmekten kendini koruyabilmektedir. Bu hedefte yine "UnsereAufgabe' de" belirgin bir şekilde vurgulanmıştır'13. Eğer bilim bu rolünden vazgeçer veya bu rolü ondan çalınırsa, yetkin olmayan danışmanlar onun yerini almaktadır. Eğer devlet bu noktada onları dinlerse, o zaman ekonomi-politik kararların yerini ekonominin sistemine zıt düşünceler ve kendi çıkar gruplarını koruyan fikirler almaktadır. Böylelikle

\footnotetext{
${ }^{13}$ Unsere Aufgabe'de devletin duracağı yer belirlenmiş ve güç gruplarına nasıl nötr yaklaşması gerektiği dillendirilmiştir.
} 
düzen bozularak, kaosa yol açılmaktadır. Çünkü bunlar bilinçli veya bilinçsiz bir şekilde kendi çıkarlarına bağlıdır ve ekonominin bütününü görmemektedirler. Ordoliberalizmin "iktisadi düzen politikasının" amacıysa, tüm insanları kapsayan ve uzun vadeli hukuki bağlayıcılığı olan davranış normları sistemini kurgulamaktır. Gerçi normatif bağlamda iktisadi düzen düşüncesi sadece kapitalist ekonomilerle sınırlı değildir, ama Alman anlayışı "rekabet düzeninin” liberal konseptine yöneliktir. Böylece aktörler özgür karar verme hakkına sahip olacaktır. Özgürlükçü bir düzen doğrudan ekonomik aktörlerin üretimine, tüketimine, tasarrufuna, kredilerine vs. karışmaz, ama bunun yerine bireylerin bu süreçleri yönettiği genel kurallar tanımlamaktadır. Doğrudan piyasa sürecine müdahil olan düzenlemelereyse "süreç politikası" denmektedir. Politik merciler bu tür müdahaleleri daha ziyade işsizliği azaltmak, enflasyonu önlemek, büyümeyi arttırmak vs. için bulunmaktadırlar. Böhm'e göre; "bugün hukuk ve ekonomi biliminin arkadan koştuklarına, belirli bir katkl sağlamadıklarına, manevi bir gü̧̧ olmadıklarına dair eleştirileri her yerde duyabilmekteyiz. Bu türden bir eleştiriyi dikkate almamak demek ise, durumun ciddiyetini anlayamamak demektir. Çünkü gerçekten de her iki bilim dall, Almanya'daki hukuk ve ekonomi politik kararlar üzerinde artık etkin değildir. Bunun her zaman böyle olduğunu iddia eden kişiyse, bütünüyle yanılmıştır. Hukuk ve ekonomi bilimi kurucu güçlerdir. Hiç şüphesiz bu iki bilimin tahttan indirilmesi çok zararlı olmuştur"'(Böhm,1980c:197-198).Bilim adamları sonuçta ekonomik çıkarları olmayan, bağımsız, ve nesnel bilgiye sahip oldukları için, sürekli genişleyen ve uzmanlaşan bilgileri sayesinde alınması gereken ekonomik tedbirler konusunda en doğru hükmü verebilecek olan insanlardır.(Böhm,1980c:197-198).

\section{BÖHM'ÜN ANAYASAL EKONOMISİ VE ÖZEL HUKUK TOPLUMU}

Böhm, Freiburg Okulu kurucularındadır, onun eserlerinde özellikle rekabetçi piyasalardaki özgür fiyat oluşumu önemli bir rol oynamaktadır. Böhm öğretisinde sürekli olarak ekonominin ne kadar yönetilmesi gerektiği irdelenmektedir. Hedef daima serbest mal hareketini teminat altına almaktır. Özellikle her tür kartel oluşumunu açık tehdit olarak niteleyerek, bu durumun, ekonominin serpilmesini ve toplumsal özgürlüğü kısıtlamadan hangi ölçüde ortadan kaldırılabileceğini araştırmaktadır. Bunu sosyal-Hristiyan insan anlayışını esas alarak yapmaktadır. ${ }^{14}$ İlk olarak tüm ekonomik faaliyet ve sosyal davranışlar esas itibarla meşru ve meşru olmayan kurallar çerçevesinde gerçekleşmektedir. Ayrıca söz konusu düzen yasalarının karakteri, aynı zamanda ortaya çıkan çerçeve içerisindeki ticari düzende de kendini göstermektedir. ${ }^{15}$ İkinci olarak ise, hukuk alanındaki seçilebilir kurallar, siyasi organize edilmiş bir topluluğu sistematik biçimde şekillendiren ve bir arada tutan en önemli enstrümandır. Bu ortak temel düşünce etrafında her iki araştırma programını, analiz ve açıklamaya yönelimli bilgilenme merakıyla pratik düzen, sorunların çözümüne yönelik bir uygulama eğilimini birleştirmektedir. Bir yandan kural

\footnotetext{
14 Schmölders, Günter, DasMoralische in der Politik, Würdigung Franz Böhmszudessen 75. Geburtstag, FrankfurterAllgemeineZeitung, 14 Şubat 1970.
} 
ve hukuk düzeni ve serbest ticaret düzeni arasındaki etkileşimi aydınlatmaya, diğer yandansa bu etkileşimin 1şığında hangi kuralların amaca hizmet ettiğini tespit etmeye çalışmaktadır.

Ekonomik anayasa konseptiyse Freiburg Okulu'nda hukuk ve ekonomi biliminin bağdaştırılmasını amaçlamaktadır. Ekonomik süreçlerin esas itibarla hukuki-kurumsal çerçeve koşullarından bağımsız olmadığı söylenmektedir. Ayrıca söz konusu yasaların, gerçek ekonomik bilgilenmenin kendine has niteliklerini bilmeden düzenlenemeyecekleri belirtilmektedir. Bu anlamda Böhm "Rekabet Ve Tekel Savaşı" (Wettbewerbund Monopolkampf) isimli makalesinde "klasik öğretiyi ekonomi dilinden hukuk diline çevirmekten" bahseder ${ }^{16}$ (Nörr,1994a:114). Hukukun ekonomikleştirilmesiyse, ancak ve ancak hukuk bilimine ve hukuk uygulamasına söz konusu kuralları oluştururken gerçeğe yakın davranmaları gereklilikleri hatırlatılabilir. Böhm 1937 yılında kaleme aldığı "Ekonominin Düzeni” (DieOrdnung der Wirtschaft) isimli yazısında "hukuksal çalışmaların büyük ölçüde ekonomik teorinin sonuçlarına bağlandığını" yazmaktadır (Böhm, Eucken, Doerth,1937:14) Başka bir noktadaysa, Böhm; "Biz hukukçular, hukuk bilimi dışında bu bilimi o kadar iyi anlamalıyız ki, onu hukuki olarak değerlendirebilmeliyiz ve hukuksal çerçeve içerisine alabilmeliyiz. Biz bu işe ekonomik yönden başlamalı ve anayasa hukukuna uygun hale getirerek tamamlamaliyı"” (Böhm,1960:50). Böhm için ekonomik anayasal kurallar bireyin özgürlüğünden yola çıkmalıdır.

Böhm; özel hukuk toplumu konsepti içerisinde, hiçbir şekilde toplumsal sözleşme düşüncesini açıktan referans almamaktadır. Ama onun özgür ve eşit hakka sahip kişilerin oluşturduğu kurallar bütünü, esas itibarla insanların gönüllü olarak anlaştıkları düzene yönelik toplumsal sözleşme teorilerinden de uzak değildir. Böhm özel hukuk toplumu ifadesini iki anlamda kullanmaktadır. Bir yanda tarihsel olarak tanımlanabilecek toplumsal düzeni referans alır, diğer yandaysa reel anlamda var olan toplumsal düzenlerin ölçülebildiği genel düzen idealini kast etmektedir. Böhm için önemli olan bu anlamıdır. Böhm'e göre bütün toplumsal düzenlerde her zaman “özel hukuk boşlukları vardır”(Böhm, 1980b, 105). İnsanlar gönüllü katıldıkları bu birliklerde, eşit hak sahibidirler. Bu özel hukuk toplumu, söz konusu alanlarda geçerli olan düzen prensipleri, ayrıcalıkları yok edebildiği ve genel norm haline gelebildikleri ölçüde toplumlar için etkili olmuşlardır. Bu bağlamda Böhm'ün Fransız devriminin tarihsel rolüne vurgu yapan "feodal ve ayrıcalıklı toplumun bir hukuk toplumuna dönüşümü" ifadesi özel hukuk toplumu konseptinin ikinci anlamı olan “düzen ideali” bağlamında ilginçtir. Böhm Fransız devriminin ana hedefinin, "insan haklarını savunmak- feodal hakların ilgası-tüm ayrıcalıkların kaldırılması için siyasi yasama gücünün sınırlandırılması ve kontrolü” olduğunu ifade ederek, aynı zamanda özgür ve eşit bir toplum idealinin temel argümanlarını da savunmuş olmaktadır (Böhm,1980:108 -196). Devlet, öncelikle düzeninin oluşumunda eşit katılım hakk1 ve özgür tercih hakkı, sonra ekonomi ve toplumsal düzlemde ayrıcalıksız ve ayrımcılık yapmayan bir hukuk düzeninin garanti altına alması önemlidir. Ordoliberal anayasal ekonominin yola çıkmış olduğu normatif

\footnotetext{
${ }^{16}$ (Nörr,1994:114) bu eseri 20. Yüzyılın hukuk biliminde çığır açan eserlerden biri olduğunu belirtir.
} 
bireysellik, aynı şekilde özel hukuk toplumunun düzen idealinde bulunmaktadır. Bunun normatif ölçütüyse "bireysel otonomi," yani sosyal aksiyomların ve toplumsal düzenlemelerin meşruiyetlerinin son kaynağına gönüllü iştiraktir. Bu ölçüt özel otonomi konseptiyle ve düzenleyici özel hukukla ifade bulmaktadır(Böhm,1980b:105). Özel otonomi kavramı burada özel hukuk çerçevesinde davranış ve antlaşma özgürlüğü olarak anlaşılmaktadır. Özgür ve eşitlerin oluşturduğu siyasi düzenin olduğu her yerde, bu ölçüt sorgusuz sualsiz devlet anayasasının meşruiyetinde geçerli olmalıdır(Böhm 1960a:34).

Anayasal ekonomide bireysel otonomi postulatı, özel hukuk ilişkileri düzleminden kolektif politik eylem düzlemine taşınmaktadır. Tıpkı özel hukukun buna dâhil olan taraflara daha iyi pozisyon sunduğu gibi, insanlar aynı kurallara tabi olarak da karşılıklı bazı avantajlar elde edebilmektedir. Özel hukuk birliklerine katıldıkları her yerde, zaten bunu özel hukuk süjeleri olarak yapmaktadırlar. Bir topluluğun vatandaşı olaraksa, bunun kurallarına uyarak, yani devlet düzenine riayet ederek yapmaktadırlar. $\mathrm{Bu}$ yüzden alt anayasal düzlemde mutlaka karar alma özgürlüğünden vaz geçmek gerekmektedir. Böylelikle ortak kurallara bağlanmanın avantajlarına ulaşıla bilinmektedir. Nasıl ki özel hukuk antlaşma ilişkilerinde gönüllü onay verme, belirleyici olan meşrulaştırma prensibiyse ve tek indikatör karşılıklı dönüşen avantajsa, bu bağlamda normatif bireyselcilik perspektifinden, hatta devlet örneğinde bile daha farklı bir meşrulaştırma prensibi ve farklı bir indikatör olamamaktadır. Böhm'ün düşüncelerine eleştirel yaklaşanlar olmuştur.

Nörr'ün eleştirel yaklaşımına göre, Böhm ve ordoliberalizm tarafından savunulan düzen tasavvuru “özel hukuk kaynağı ve taşıyıcısıdır ve kendi başına bir alanı yoktur. Bunun yerine özel hukuk toplumu ve piyasa mekanizmasıyla bağdaştırılmaktadır. Özel hukuk otonomisi nihayetinde sistemin politik kararlarına dayanmaktadır." ${ }^{17}$ Eğer bireysel özgürlüğün iki konsepti arasında ayrıma gidilirse, yani “özel otonomi” ile “anayasal otonomi” belki bu sorunun çözümüne katk1 sağlayabilmektedir(Norr,1994a:78-90).Özel otonomi burada bireysel davranış haklarını kapsamaktadır. Toplum içerisinde geçerli olan kurallar veya anayasal düzen tarafından tanımlanmaktadır. Hakların kullanılması sırasında hem devletin hem özel kişilerin müdahalelerinden korunmaktadırlar. ${ }^{18}$ Sonuçta bir topluluk üzerine verilecek kararlar, zorunlu olarak kollektif tercih meselesidir. Anayasal düzlemde esas itibarla bireysel özgürlük ve otonominin korunması meselesi, kolektif seçim esnasında bireyin karar alma özgürlüğünün bulunup bulunmadığı önemlidir. Aynı şekilde özel hukuk düzeni çerçevesindeki sosyal sorumluluklar, katılımcıların bunu özgür iradeleriyle kabul etmeleri sonucu meşrulaşmaktadır ${ }^{19}$ (Böhm, 1960a:26).Özel hukuk toplumu bağlamındaki anayasal uzlaş1, ancak özgür onayın bulunması durumunda meşrulaşmaktadır. Devlet yapısının bölgesel ve nesiller arası bir birlik olması nedeniyle, anayasal otonominin özel hukuk birliklerine göre bu düzlemde daha fazla

\footnotetext{
${ }^{17}$ Serbest rekabet için verilen anayasa kararı, aynı zamanda rekabet tarafindan oluşturulan ekonomik düzenin özel hukuku içinde anayasal karar anlamına gelir. Aynı şekilde özel hukuk kurumu da kurucu gücün iradesine dayanır.

${ }^{18}$ Böhm bunu çok anlamlı bir biçimde ifade etmiştir: Devlet otoritesini temsil edenler dahi, eğer özel hukuk alanında satıcı, alıcı, mülk sahibi ve hisse sahibi olurlarsa, güçlerini ve otoritelerini gardoropta teslim etmek zorundalar.

${ }^{19}$ Burada katılımcılar birbirleriyle eş düzlemdedir. Katılımcılar arasındaki yükümlülükler ve talepler sadece antlaşmalar temelinde oluşabilir (Böhm, 1960a:26).
} 
sınırlandırılacağı ortadadır. Bireyin anayasal otonomisi, düzen kuralları seçimindeki özgürlükleri, mutlaka devletin önünde tasarlanmış bir "insan hakkı" olarak görülmelidir. Bununla birlikte özel otonomi ve bunun üzerinden tanımlanan ekonomik serbestlik hakları, bu anlamda koşullu bir tabiata sahiptirler. Sonunda meşruluklarını bu anayasal düzen altında bulunan insanların özgür onaylarıyla almaktadırlar. Özel otonominin anayasal hale getirilmesiyle birlikte "gerçi ekonomik özgürlük hakları zayıflar, ama aynı zamanda yeni bir meşruluk kazanırlar.” (Mestmacker, 1995:128).

\section{5. ÖZEL HUKUK TOPLUMU DEMOKRASİ VE DEVLET}

İnsanlar "bireysel ve bağımsız" bir şekilde birlikler arasında hareket ederek, düzenleyici kuralların tercihindeki özgürlüklerini kullanabilmektedirler. Bu noktada devlet yapısı içerisindeki hareket kabiliyetinin, özel hukuk birliklerine göre daha büyük zorluklar içerdiği aşikârdır. Bir birlik içerisinde anayasal otonomilerini zorunlu bir şekilde sadece diğer birlik üyeleriyle birlikte gerçekleştirebilirler (Vanberg,2005:41). Yoldaşlık-belirleyici üyeler organizasyonu bulunan politik yapılardaki demokrasi, anayasal otonomini prensibinin kurumsal yapılanması olarak görebiliriz. Özel hukuk toplumu ve piyasa ekonomisi kendi içerisinde kendini organize eden bir sistem olarak oluşur, bunun koordinasyon performansı, bireysel aktörlerin genel oyun kuralları çerçevesinde kalmaları ve fiyat oluşumları sonucu karşılıklı olarak birbirilerine uyum sağlamalarına dayanmaktadır. Özel hukuk toplumuysa kendiliğinden öz-organizasyona dayandığı için, davranış kabiliyeti ve karar alma kabiliyeti olmayan bir yapıdır ${ }^{20}$ (Böhm,1980b:115).Bu kendini organize eder, ama kendi kendine yeterli değildir. Fonksiyon kabiliyetini korumak ve düzenleyici kuralları oluşturup uygulamak için, kolektif kararlara ve kolektif davranabilen bir organizasyona yani devlete ihtiyaç duymaktadır.

Böhm'e göre, demokratik devlet bu manada bir yoldaşlık kurumu olarak görülebilmektedir. Buna üyeler özel hukuk yoluyla dâhil olmaktadırlar. Burada amaç, sadece kolektif eylemle ulaşabilecekleri ortak çıkarlara ulaşmaktır. Demokratik devlet, eylemsel kabiliyet barındırmayan toplumun icra organıdır(Böhm,1980b:110).Özel hukuk toplumu ve demokratik devlet Böhm'ün ifadesine göre, birbirlerini karşılıklı olarak tamamlamaktadır. Özel hukuk toplumu üyeleri birbirleriyle eşit ve aynı hakka sahip insan olarak karşı karşıya geldikleri gibi, aynı şekilde devlet yapısı içerisinde eşit üyeler olarak politik düzlemde yer almaktadırlar ${ }^{21}$ (Böhm,1980a:87) Böhm, "politik prensipleri ve özel hukuk toplumunu anayasallaştıran prensipleri, kapsamlı fonksiyonel bir bütün olarak kabul edilebileceğini vurgular. ” Böylelikle bu ‘fonksiyonel bütün' her ikisinin bireysel otonomi prensibini geçerli kılmaları, özel hukuk düzeninde özel hukuk olarak ve kamusal alanda anayasal otonomi olarak kabul edilmelerini sağlamaktadır22(Böhm,1961:14). Özel hukuk toplumu ve demokrasi birbirlerini karşılıklı olarak amaca

\footnotetext{
${ }^{20}$ Özel hukuk toplumukendisi karar alan ve bunu gerçekleştiren bir fenomen değildir. Sivil hukuk toplumu alanında planlanmış ve yapılmış olanlar, topluluğun üyeleri tarafından ve onların özgür iradeyle oluşturdukları birlikler tarafından planlanır ve yapilır (Böhm,1980b:115).

${ }^{21}$ Rekabet düzeni bu şekilde demokratik devlet düzeni için adeta mükemmel bir alt yapı olarak hizmet verir. Çünkü özgür insanları koordine etme düşüncesine dayanır(Böhm,1980a:87).

${ }^{22}$ Batı tipi modern demokrasiyi oluşturan devlet içerisinde halkın egemenliği, toplum içerisinde özel hukukun egemenliği ve devlet ile toplumun hukuk devleti kapsamında bağdaşmasıdır(Böhm, 1961:14).
} 
yönelik tamamlar, çünkü özel hukuk ve piyasa ekonomisi düzeninde ortaya çıan özyönetim enerjisi, devletin yapması gereken faaliyetleri büyük ölçüde kısıtlamaya yardımcıdır. Politik karar alma egemenliği büyük ölçüde etkili bir biçimde kontrol edilir ve tüm bunlar devlet yargısının etki alanının genişlemesiyle olmaktadır. ${ }^{23}$ (Böhm,1980:89; 1961,13). Devlete toplam icra içerisinde düşen rol, Böhm'e göre Politik takdire çok dar bir sınır çizecek bir içeriğe sahiptir. Eğer politik karar, sistem lehine verilirse, o zaman yasaların nasıl olacağının, hükümetlerin ne söyleyeceğinin ve mahkemelerin en yüksek prensibinin ne olacağının kararı da verilmiş olmaktadır. Bu çerçeve içerisinde ve bunun sonunda ortaya çıkan imkânlar doğrultusunda, halk için etkin bir olanak belirmektedir. Halk, hükümeti tayin edebilir ve kontrol altına alabilir ${ }^{24}$ (Böhm,1960b:55). Eğer Böhm'ün ayrıcalıksız özel hukuk toplumu konseptini, gelişimin ölçütü olarak alırsak, o zaman sosyal politik bileşenin vurgulanmasının esasında "sosyal korumacılığın” bir meşrulaştırıcısı olarak hizmet ettiğini görebiliriz. Bu şekilde git gide esneklik zayıflar ve piyasa ekonomisi sistemine uyum kabiliyeti azalır. Ayrıcalıkların olmadığı anayasal bir piyasa ekonomisinin fonksiyonlarının bu şekilde erozyona uğraması, sadece ayrıcalık peşinde koşan çıkar grupları ve bu ayrıcalıkları sağlayan politikanın işi değildir, çünkü belirgin bir şekilde hukuksal destekte almaktadır ${ }^{25}$ (Böhm,1980c:260). Hukuk burada sürekli olarak rekabet kurallarına uymayanları ödüllendirmektedir ve rekabet kurallarının gereklerini yerine getirenleri cezalandırmaktadır. ${ }^{26}$ Özellikle federal anayasa mahkemesinin kararlarında bu türden bir tandans görülmektedir. Kararlar bilhassa sosyal devlet yasalarının yorumlanmasında ve işçi hakları ile kira sözleşmelerinde görülmektedir (Lauder, 2004:24).

Böhm, “düşük bir demokraside” somut bir ekonomik politika uygulamanın mümkün olmadığını düşünür, çünkü partiler uzlaşı arayışı içerisinde tezat olan sosyal ve ekonomik anlayışları savunmaktadır.Çoğunluğa dayalı bir seçim sistemi reformu yapılmasını beklemektedir. Bu hem parlamentonun hem de hükümetin güçlenmesi anlamına gelecektir. Bununla birlikte Freiburg Okulunun bu düşüncesine göre, eğer piyasa doğal bir süreç değilse de devlet farklı bir görev üstlenmek durumundadır(Goldschmidt/Rauchenschwandtner, 2007:13-30). Bırakınız-yapsınlar "gece bekçisi devletinin" yerine devlet rekabet-piyasa ekonomisi sisteminin bir aktörü olarak piyasaya çıkmaktadır. "Piyasalar ancak büyük uğraşların sonunda oluşur ve esasında saf rekabet hiçbir zaman gerçekleşmez. Rekabet bu anlamda hükümet etme sanatının tarihsel bir hedefidir. Bunun için dikkat edilmesi gereken doğal bir gerçek değildir” (Focault, 2004:173) Focault’a göre, ordoliberalizm hem saf natüralizme ve saf piyasa liberal pozisyona mesafeli oluşu hem de kendine has devlet anlayışı nedeniyle dikkate alınmalıdır. Freiburg Okulu sadece "liberalizm içerisinde bir varyasyon değildir, liberal doktrinin temel

\footnotetext{
${ }^{23}$ Rekabet düzeni bir demokratik devlet anayasasıyla sadece devlet görevlerinin minimuma indirgemesinden dolayı değil, aynı zamanda kendi içerisinde de demokratik bir süreç olduğu için en mükemmel sonucu verir(Böhm, 1980:89; 1961,13).

${ }^{24}$ Burada devlet başından itibaren tercih edilmiş olan yöntem doğrultusunda kısıtlayıcı hükümleri kabul eder (Böhm, 1960b:55).

${ }^{25}$ Hakimler gerçi özgür seçimleri anlamış görünüyor, ama anayasal düzen politik rekabet kavramını anlamakta güçlük çekiyorlar (Böhm, 1980c:260).

${ }^{26}$ Aklı selim ve düzene uygun bir süreç için herkesin yönetim mekanizmasına aynı şekilde tabi olması gerekmektedir. Burada istisna ve ayrıcalık vs. olmamalıdır(Böhm, 1980b:164).
} 
elementlerinin yeniden değerlendirilmesidir”(Foucault, 2004: 149). Foucault, devlet anlayışının ordoliberal gelenekte farklı ve fonksiyonel meşruiyet temeli üzerine oturtulduğuna dikkat çekmektedir. Devlet sadece belirli inanışlar veya değerler (ideolojiler) üzerinde meşrulaştırılmamıştır, bunun yerine piyasa ve toplum için oynadığı fonksiyonel ve zorunlu rolü ön plana çıkartılmaktadır. Piyasalar ise doğal bir gerçeklik yerine, "bir devlet düzenlemesi” olarak anlaşılmaktadır (Miksch,1947:11). Sonuçta devletin meşruiyeti değer yargılarına göre değil, rekabet düzeninin tesisi ve korunması için zorunlu olan fonksiyonlar itibarıyla meşrudur. Kapitalizm ve modern devlet hem tarihsel hem de sistematik anlamda birbirini tamamlayıcı olarak anlaşılmaktadır. Ordoliberalizme göre, toplumsal - ekonomik teori piyasayı kabul etme veya ret etme konusunu düşünemez. Bunun yerine politik, toplumsal ve ekonomik strüktürlerin rabıtası ve şekillendirme olanakları üzerinde durulmaktadır. "Piyasa" ne karşı konulmaz bir kaderdir (bırakınız-yapsınlar) ne de karşı çıkılması gereken bir sonuç değildir (sosyalizm). Bunun yerine piyasa strüktürleri bazı şartlar barındıran ve toplumsal bağlamda şekillendirilmesi gereken strüktürlerdir. Ordoliberalizm işte özellikle piyasa-devlet entegrasyonu itibarıyla anlamlıdır. ${ }^{27}$ Ordokapitalizm konseptine baktığımızda, ilk önce ideolojiye eleştirel bakışını ve çıkar gruplarına eşit mesafeli oluşunu görebilmekteyiz. Bu şekilde entegre bir ekonomik politikayla ne devlet-piyasa düalizmini, ne de ekonomi-sosyal politikalar çatışmasına girmeden, toplum içerisindeki gerilim alanlarını vatandaş eğilimli bir politikayla ortadan kaldırmaya çalışmaktadır.

Ordo-liberalizm konsepti, çıkar gruplarına eşit mesafelidir. Entegre bir ekonomik politikayla ne devlet-piyasa düalizmini, ne de ekonomi-sosyal politikalar çatışmasına girmeden, toplum içerisindeki gerilim alanlarını vatandaş eğilimli bir politikayla ortadan kaldırmaya çalışmaktadır. Toplumun tüm üyelerine özgürlük ve onur veren sağlam bir ekonomik ve toplumsal strüktürü tesis etmektir. Fakat bununla birlikte bu türden "kuvvetli bir devlet", vatandaşların özel hayatına giren ve onları git gide daha fazla yönetmeye çalışan "total bir devlet" anlamına gelmemektedir. Hayır, burada topluma bir enstrüman olarak hizmet eden ve "etkili bir devlet" kast edilmektedir. Etkili bir devlet, ekonomiye belirgin ve genel düzenleyici kurallar koymaktadır. Bu şekilde eşit haklara sahip bireyler için, piyasa rekabetinin sosyal fonksiyonunu merkezi olmayan bir koordinasyon süreci olarak garanti etmektedir. ${ }^{28}$ Devlet piyasaların oyun kurallarını belirlediği ve piyasalar devletin fonksiyonunu meşrulaştırdığı için, her ikisi birbiriyle bağlantılı ve bağımlıdır. Bu manada Freiburg yaklaşımının hem bireysel ilişkileri devletin tasarımlarıyla şekillendirmeye çalışan siyasallaşmaya hem de sosyal çıkar ve ortak refahı bireysel düzleme kaydırmaya çalışan özelleşmeye karşı çıkmaktadır. Sosyal çatışmayı ortadan kaldırmak isteyen, toplumsal olayların ideolojiden arınmış bir analizi söz konusudur. Piyasa ve rekabet bu yüzden bu hedefe ulaşmak için araçtır ve politik çerçeveye ihtiyaç duymaktadır. Eucken'e göre sosyal problem "ancak ekonomi politikasının ve sosyal politikasının tüm birimlerini koordinasyonuyla” çözümlenebilir(Eucken,1949:11). Ordo kapitalizmin temel hedefi, toplum

\footnotetext{
${ }^{27}$ Eucken çağın tartışmaları içerisinde kapitalizm kavramını ret etmiş ve ordo-kapitalizm anlayışını ortaya koymuştur.

${ }^{28}$ Sonuç itibarıyla bu adalet anlayış1, Smith düşüncesine de ve onun eserlerinde yer alan fikirlere de uygundur.
} 
içerisindeki farklı çıkarları eşitlemeye dönüktür. Düzen ekonomisi siyasileşme ve özelleştirme tandansları arasında bir denge talep eder ve bu bağlamda, özel çıkarlara karşı devletin nötr olmasını ister.

Grossmann-Doerth' göre, piyasaların siyasileşmesi durumunda, modern devlet faaliyeti sosyal düzenleyici olarak kullanılabilmektedir. Buna göre toplumsal gelişimin temel problemi, sosyal olayların "özelleştirilmesinde" yatmaktadır. Toplumsal düzen ve sosyal eşitlik bu durumda sadece kapitalist ekonominin bir fonksiyonu olarak işlev görmektedir. Siyasileşme problemleri sonuçta devleti güçsüzleştirir. Bırakınız-yapsınlar yaklaşımının desteklediği özelleştirme tandansları, vatandaşın piyasalardaki konumu zayıflatır. Ordoliberallerin entegre edici bakış açısına dayanan ordo-kapitalist pozisyonsa, belirgin bir şekilde eşitleyici ve nötr bir tutuma dayanmaktadır. Siyasileşme ve özelleşme temayüllerine yönelik argümanlar, buna göre tartılmalı ve sonunda entegre ve nötr bir toplumsal konseptte dönüştürülmelidir. Ordoliberal düzen tasavvurlarının önkoşuluysa, kuvvetli ve her türlü toplumsal baskıdan uzak devlettir ${ }^{29}$. Ordoliberal iktisat teorisine göre devletin iki temel ekonomi-politik ilkesi vardır. "Devletin ekonomi-politik faaliyeti, ekonominin düzen formunun şekillenmesine yönelik olmalı, ama ekonomik süreci yönetmeye kalkmamalıdır"(Eucken,1960:336).Devletin ekonomik süreci yönetme yükünden kurtulmasıyla birlikte, rekabet düzenini ayakta tutabilecek tarafsızlı̆ga ve otoriteye sahip olmalıdır. Buna göre devlet "hakem ve piyasa polisi” olarak hareket etmelidir. Ordoliberaller genel anlamda devlet müdahalesini ret ederler(Eucken, 1960:334).

\section{REKABET DÜZENI}

Böhm'ün en büyük başarısı özellikle anti tröst yasalarında görülmektedir. Böhm "Justiz” isimli dergide 1928 yılında yayınlanan "Özel Güç Sorunu - Tekel Sorusuna Bir Katk1” (Das Problem der Privaten Macht - EinBeitragzurMonopolfrage) isimli makalede, kendi zamanında egemen olan kartel lehtarı hukuk uygulamalarını ve hukuk öğretisini eleştirmektedir. Bu noktada bunların ticari özgürlüğün ayrıcalıktan arınmış bir özel hukuka dayandığını görmezden geldiğini ve rekabetçi-piyasa ekonomisine yönelik bir ekonomik anayasa etrafında, kamusal kurumların ticari özgürlüğü hem devlete hem de özel egemenliğe karşı koruması gerektiğini belirtmektedir ${ }^{30}(B o ̈ h m, 1960 a: 39)$. Hem Böhm hem de ordoliberaller, liberalizm geleneği içerisinde kalarak "bırakınız yapsınlar" anlayışından uzaklaşmışlardır. Çünkü bu şekilde piyasa ekonomisinin "kendi kendini yöneten” bir düzen olduğu anlaşılmış, ama bunun "kendi kendini oluşturan” bir düzen olduğu anlaşılmamıştır. Böhm, "rekabetin bir doğal olmadığı ve bunun yerine hukuk düzeninin bir sonucu olduğunu” belirtmiştir (Böhm,1937:120).

\footnotetext{
${ }^{29}$ Devletin etkin olduğu alan ise, piyasa ekonomisi düzeninin gerekleri tarafından belirlenir ve sınırlandırılır (Marchal 1970:96).

30 Anayasal hukuku bağlamında bakıldığında, ticaret özgürlüğü sisteminin esasında ekonomik hayatın olumlu anlamdaki bir anayasası olduğu görülecektir. Bu sistemin hayata geçirilmesi, aynı zamanda ekonomik-sosyal işbirliği sürecinin şekil ve türü üzerinde bir uzlaş1 gerektirir (Böhm, 1960a:39, 1944:107).
} 
Böhm'ün “devletin rekabeti düzenlediğini” yazması çoğu yerde yanlış anlaşılmıştır. Rekabetin kendiliğinden bir kökensel fenomen olduğu ve bunun kıt kaynaklar dünyasında engellenemez olduğunu Böhm'de bilmektedir ve rekabetin çok farklı biçimde ortaya konulabileceğini savunmaktadır. Hangi rekabet formlarının yıkıcı olduğu ve hangilerinin prodüktif olduğu ise, insani birlikte yaşam düzeni için belirleyici bir sorudur. Sonuçta kıt ürünün olduğu her yerde rekabet olacaktır, ama bu rekabetin kendiliğinden sosyal prodüktif bir formda gerçekleşmesini beklemek doğru değildir. Bunu garantiye almak için uygun bir yasal düzenle rekabet kurulmalı ve denetlenmelidir. Sonuçta Böhm kendisi için kökensel fenomen rekabetin değil, "kamusal hukukun ortaya çıkardığı rekabetin” önemli olduğunu belirtmiştir(Böhm,1937:125). Ekonomik rekabetin yaşanacağı "kurallı düzenin" kamusalhukuksal bir karakteri vardır. Bu düzende rekabet tüm katılımcılara hizmet eden bir rol oynamaktadır. Böhm ve Freiburg Okulu bu türden bir rekabeti "verime dayalı veya performans rekabeti” olarak tanımlamışlardır(Böhm,1937:137).Ekonomik rekabetin "hukuksal düzeni olan bir performans rekabetinin oyun kurallarına göre" belirleneceği tasavvuru esas itibarla katılımcılara doğrudan zarar veren önlemler almak yerine, onları çekici performans teklifleriyle piyasaya çekmeye dayalıdır (Gerber, 1994: 53). Tabi ki bu türden bir piyasa düzeni kurmak ve korumak için, sağlam bir hukuk düzenine ihtiyaç vardır. Şiddet ve dolandırıcılık bu şekilde önlenebilmektedir (Böhm,1937:105). Devlet ayrıca her türlü rekabet olanağını piyasalara sunmalıdır. Bu bağlamda Böhm "performansa dayalı rekabetin oyun kurallarının amacı, baskıyı bir etki unsuru olarak kullanan rekabet stratejilerinin kullanımını dışlamaktır”31 (Böhm:1960a:32). Böylelikle Böhm'e yönelen eleştiriler hedefini bulmaz, çünkü Freiburg ordoliberalleri performans rekabeti konseptleriyle ekonomik rekabet içerisinde "performans" olarak değerlendirilebilecek bir liste oluşturma derdinde değiller. Hayır, bunun yerine negatifi sınırlandırmak isterler ve düzen prensibinin gönüllü takasa dayalı rekabet anlayışıyla uyumlu olmayan stratejileri engellemek istemektedirler. Rekabetin “oyun kurallarının” en iyi şekilde nasıl tanımlanacaklarıysa, sabit bir tanım değildir ve söz konusu kuralların reel etkilerinin düzen ekonomik bir analizini gerektirmektedir. ${ }^{32}$

Freiburg ordoliberallerinin performans rekabeti olarak tanımladıkları, son yıllarda ekonomi retoriğine "tüketici egemenliği” olarak geçmektedir. Her konseptin temelinde Smith'in düşüncesi olan "üretimin kendisinin bir amaç olmadığı ve tüketicinin isteklerini tatmine yönelik olduğu” fikri yatmaktadır (Vanberg, 2005: 39). Böhm bunu "tüketici piyanist olarak doğrudan ekonomin tuşlarının önüne oturmaktadır” biçiminde yorumlamıştır. Böhm'ün belirttiği üzere, klasik ekonominin kazanımları sadece serbest piyasa ekonomisinin bununla ilgili performans niteliklerini keşfetmekte yatmaktadır ${ }^{33}$

\footnotetext{
${ }^{31}$ Böhm burada "engelleyici rekabet sadece başkasının üretimini bozmaya yöneliktir ve kendi ürününü kaliteli hale getirmeye çalışmaz. Bu engelleyici stratejiler kendi performansın iyileştirilmesini içermez, rakiplerin performansını düşürmeyi hedefler" (Böhm:1960a:32).

32 İzin verilmiş ve yasaklanmış rekabet arasındaki çizginin nasıl çekileceği konusu, ne zaman performans rekabetinin bulunduğu ve ne zaman engelleyici rekabet bulunduğu konususadece farklı ekonomik anayasaların araştırılması ölçeğinde tespit edilebilir. Bunu ekonomi bilimi yapar. (Böhm, Eucken, Grosmann-Doerth,1937:).

33 "Piyasa ekonomisinin insanlar ve halklar tarafından pratikte uygulandığını söyleyebiliriz, ama onlar tarafından keşfedilmemiştir. Piyasa ekonomisi sisteminin düzen-strüktürünün keşfiyse, onun uygulanmasından binlerce yıl sonra
} 
(Böhm, 1980: 236-238). Smith'in görünmez el teoremine göre, piyasa ekonomisi rekabet düzeni "bir görünmez el” tarafindan bütün bireysel çıkarları koordine eder ve toplumsal çıkara uygun hale getirmektedir. Ekonomik aktörler hiçbir devlet katkısı olmadan sadece kişisel kazanç sağlama isteğiyle "farkında olmadan ve bunu hedeflemeden toplumsal çıara hizmet etmektedirler" (Smith,1926:316).Fakat ekonomik liberalizmin başarısızlığının nedeni tam olarak budur. Çünkü Smith burada bırakınız - yapsınlar prensibinin, rekabetin bazı türleri için uygun bir anlayış olduğunu ve hepsi için geçerli olmadığını görememektedir. Zira evrenselleştirilebilecek genel piyasa çıkarımları elde etmek için, “verime dayalı rekabet gereklidir”(Böhm,1933:210) ${ }^{34}$. Freiburg ordoliberalizmin özel yanı, onların piyasa ekonomisi rekabet düzeninin arzulanan fonksiyonel niteliklerinin, kendiliğinden oluşan doğal bir rekabetin ürünü olarak görmemeleri ve bunun yerine ancak oyun kuralı veya performans rekabeti kuralları uygulandığı oranda kendisini gösterdiğine inanmalarıdır ${ }^{35}$ (Miksch,1947:220). Piyasa ekonomisi verimliliğini rekabet özgürlügüne borçludur. $\mathrm{Bu}$ da performans rekabeti üzerinden tanımlanmış düzenleyici kurallar bütünüdür, ama bu tanım izin verilen stratejiler bağlamında pozitif bir tanım değildir ve yasak eylemleri kapsayan bir tanımlamadır. Rekabet düzeni boyutunda özel hukuk otonomisini kendi çıkarları bağlamında kabul edip etmeme şansı bireye bırakılmıştır. Sonuçta bunun sosyal sorumluluğu, kendisine verilen düzenleyici kurallalar çerçevesinde yapılmaktadır ve kararlarının merkezine refahın artırılması ölçütü kabul etmesi değildir. Özel hukuk otonomileri arasındaki ilişkinin, tüm katılımcılar için hizmet eden bir ticari düzen oluşturmak ise, nihayetinde düzenleyici kurallara bağlıdır (Böhm, Eucken,Doerth1937:27).Ayrıca düzenlemeyi, kuralların söz konusu başarıyı yerleştirmesi ve etkili bir şekilde uygulaması ise politik tabiatlıdır. Rekabetçi bir ekonomik anayasanın kendine has performans kabiliyeti, özellikle oyun kurallarının doğru tanımlanması durumunda tekil bireylerin topluma yönelik sorumluluklarını ortadan kaldırır ve motivasyon-beceri-bilginin ortaya çıkmasını sağlamaktadır. Böhm'e göre, performans rekabeti düzeni yerleştirmek için "bireysel çıkarı ve toplumsal çıkarı aynı anda idare etmek ve eş zamanlı olarak yol gösterici ile bariyer koyucu sistemini otomatik harekete geçiren bir yapı kurmaktır ” (Böhm,1960b: 61).

$\mathrm{Bu}$ bağlamda piyasa ekonomisi rekabet düzeni bir nevi sosyal-pakt olarak görülebilir. Burada katılımcılar karşılıklı olarak bazı sorumluluklar üstelenir ve ortak çıkarlardan faydalanırlar. Devlet rekabet düzeninin koruyucusudur (Eucken,1990:327). Ve bu paktın düzenini korur ${ }^{36}$ (Böhm

\footnotetext{
gelmiştir, ancak 18. Yüzyılın ortalarında oluşturulmuştur. Şüphesiz bu insanlığın en büyük ve bilimsel başarılarından bir tanesidir" (Böhm,1980:236,238).

${ }^{34}$ Çünkü burada işletmeler fiyat-kalite-koşul bağlamında tüketicilerin problemlerini çözmek için çalışır. Zarar verici veya engelleyici bir rekabet ise ki burada rakipler birbirlerini engelleme yoluna giderler, bu bağlamda verimli olmaz. Hatta devlet ekonomik düzen politikalarıyla, rekabet için genel ve evrensel kurallar koymazsa, verim bağlamında özellikle bu istenmeyen formlar etkin olur. Çünkü esas itibarla rekabet, kendi kendini ortadan kaldırma tandansı içerisindedir, yani modern ekonomikoyun teorisi itibarıyla "sosyal ikilem-açmaz" durumuna tabidir. Eğer oyun teorisinde bir deneme yapar ve işletmeleri "rekabet kurallarına uyup-uymama konusunda" özgür bırakırsak, o zaman her işletmenin diğer rakiplerinden bağımsız bir şekilde, rasyonel bir eğilimle "rekabet kurallarına uymadı̆̆ını" görebiliriz (Böhm,1980:242-244 ).

35 İşte bizi 19. Yüzyılın ekonomik liberalizminden ayıran budur, çünkü biz bırakınız yapsınlar ile rekabeti birbirinden ayırmasını öğrendik, biz belirgin bir şekilde bir düzen kurmak niyetindeyiz ve ekonomik anayasayı düşünüyoruz(Miksch,1947:220).

${ }^{36}$ Hukukun ve hükümetin görevi burada düzen çerçevesini oluşturmak, korumaktır. Bu sadece anayasal bir görev değildir ve aynı zamanda halkın çıkarınadır, sonuçta herkes devletin bu görevi ciddiye almasından memnun olur (Böhm, 1980b:158).
} 
1980b:158). Ama zorluk sonuçta herkesin avantajlardan faydalanmak istemesi ve sorumluluklardan kaçmak istemesinden ileri gelmektedir. Böhm'ün belirttiği gibi bunu iki yolla deneyebilirler. İlkin katılımcılar piyasa rekabeti "oyununda" oyun kurallarını zedeleyerek avantaj sağlamaya çalışabilir. İkinci olarak ise, katılımcı olarak politik süreç içerisinde kendileri için istisnai kurallar aldırmaya çalışırlar. ${ }^{37}$ (Böhm,1980b:164). Etik sistemlerde katılımcılar kendi çıkarları doğrultusunda karşılıklı olarak bu kurallara bağlanırken bunun mutlaka bedelini öderler, ama piyasa ekonomisi rekabet düzeninin etik kalitesi esasında onun anayasal "sosyal-paktında" bulunmaktadır(Vanberg 2002:61,Armack,1976:256). Böhm piyasa ekonomisinin kendini kontrol etme sisteminden "oldukça büyütülmüş bir park alanı" olarak bahsederken bunu kast etmiştir. Bu "bir dizi politik, hukuki, sosyal, medeni ön koşulun olmasını ve sürekli iyileştirilmesini şart koşmaktadır "38 (Böhm, 1980c:200 ). Az çok işleyen bir hukuk düzeninde rüşvet, hırsızlık vs. gibi oyun kurallarına aykırı davranışların belirli düzeyde tutulacağı varsayılmaktadır. Böhm ve Freiburglu meslektaşları özellikle rekabet düzenini özel hukuk enstrümanları üzerinden kısıtlayan davranışlarla ilgilenmektir (Böhm,1960:63). Böhm argümanlarında rekabetçi bir ekonomik anayasa için yasal oluşumun sistemik bir önceliği vardır. $\mathrm{Bu}$ anayasal özel hukukun da önündedir. Bu noktada hangi ekonomik anayasal düzenlemelerin öncelik sahibi olacağı ise, sonuçta yasaların yetkilendirdiği kurullarda anayasal düzlemde tayin edilmektedir. Eğer burada piyasa ekonomisi rekabet düzeni tercih edilirse, o zaman özel hukuk antlaşma özgürlüğüne bazı sınırlar getirilir. Böhm'e göre özel hukukun tanıdığı özgürlükler, ekonomik anayasa üzerinden koyulmuş olan düzen prensiplerini ilga edemez ${ }^{39}$ (Böhm,1960a:40). Sonuçta ekonomik anayasa, rekabeti özel hukuk yoluyla kısıtlamaya kalkan emellere karşı korunmalıdır (Böhm, 1960a:37, 42). Organize grupların oyun kurallarını ortadan kaldırmak için kullandıkları bir diğer etkili yol ise, politik arenaya etki ederek rekabete karşı koruma veya sübvansiyon almalarıdır. Böhm çıkar gruplarına siyasi arenada verilen ayrıcalıklar konusunda, bunun "ciddiye alınması gereken bir sistem zayıflığı" olduğunu belirtir. Piyasa ekonomisi özel hukuk toplumunun yaşadığı bu zayıflığın, gerçekte vazgeçilmeyecek olan özel hukuk ve demokratik yurttaş hakkı göz önünde tutulduğunda "tedavisi zor bir hastalık" olduğunu söyler (Grossekettler,1999:64,Böhm,1980b:166). Böhm’e göre ne çıkar gruplarının karş11ıklı dönüşüm içerisinde kontrollerine ne de hükümetin düzenleyici tedbirlerine bu konuda güvenilemez. Çünkü monopol-kartel oluşumun nedenini, var olan psikolojik egemenlik dürtüsünün yanında, özellikle devletin ekonomik ve finans politikası içerisinde görmektedirler. Onların görüşüne göre monopoller devlet politikalarıyla oluşmaktadır. Belirli hukuki formlar ve vergi ayrıcalıkları sayesinde büyük organizasyon tipleri ortaya çıkmaktadır. Böhm'e göre, bunu önlemenin en iyi yolu "anayasal siyasi

\footnotetext{
${ }^{37}$ Burada söz konusu olan günah, katılımcıların normal düzen içerisinde elde edebilecekleri gelirlerini, politik etki ve devlet üzerinde baskı yaratarak düzeltmeye çalışmasıdır(Böhm, 1980b:164).

${ }^{38}$ Rekabet ekonomisi kültürel bir mucizedir ve yüksek bir yönetim kültürü, belirli bir ilkesel sağlamlık, bireysel özgürlüklere riayet, bireysel özgürlük aşk1, bu özgürlüğü savunma iradesi ve hukuk bilinci ister”. Böhm'e göre klasiklerin önemli hatası, bilinçli kültürel performansın söz konusu düzen faaliyetleri içerisindeki payını görmezden gelmeleriolmuştur(Böhm,1980c:200).

${ }^{39}$ Yatırım yapma özgürlüğ̈̈n yasal hale getirilmesi, esas itibarla kişiyi serbest bırakmaktadır, ekonomiyi değil. Yok eğer durum tersine dönerse, devlet anarşik ekonomik düzeni bir kenara iter ve yerine yenisini ikame eder, ki devlet bunu yapmakla yükümlüdür (Böhm, 1960a:40).
} 
ilkesel kararlarda" yatmaktadır. Çünkü devlet verdiği istisnai tavizler sonucu çıkar gruplarının hedefi haline gelmiş̧ir ve böylece esas işi olan düzenleyici tedbirler alamaz ve herkesin çıkarına olan çerçeveyi koruyamaz hale gelmiştir. Bu teşhis doğrultusunda devletin görevi söz konusu bu "sistem zayıflı̆̆ını" ortadan kaldırmaktır (Oswalt,2007:7-15). Ayrıca ekonomi ve finans politikalarında rekabeti teşvik edici tedbirler alınmalıdır. Bu şekilde monopollerin oluşması engellenmiş olmaktadır. Buna rağmen var olmaya devam eden monopollerse, bağımsız bir monopol dairesinin denetimine girmelidir. Bu resmi dairenin vazifesi, monopolleri rekabete dayalı piyasa ve fiyat istikrarına uymalarını sağlamak olmalıdır. ${ }^{40}$ Ekonomik anayasa, milli ekonomik hayatın düzeni üzerindeki politik karar olarak görülmelidir.

Devlet bu noktada rekabetin etkili çalışması ve bununla bağlantılı refahın ortaya çıkarılması için yasal çerçeveyi koymak durumundadır. Topluma bir enstrüman olarak hizmet eden ve etkili bir devlet kast edilmiştir. Bu türden etkili bir devlet, ekonomiye belirgin ve genel düzenleyici kurallar koyar. Eşit haklara sahip bireyler için, piyasa rekabetinin sosyal fonksiyonunu merkezi olmayan bir koordinasyon süreci olarak garanti eder. Yatırım özgürlüğü ve mülkiyetin korunması mutlaka devlet tarafindan meşrulaştırılmalı ve teminat altına alınmalıdır, çünkü piyasa ekonomisinin sömürüyü engelleyen etkisi sadece bu şekilde devreye girmektedir. Böhm ayrıca kazancın/karın şeytanlaştırılmasını, şirketlerin sömürüyle eşdeğer tutulmasını ve piyasa fiyatlarının idari niteliğinin sorgulanması konusunda da eleştirel bir tutum sergilemiştir. Böhm'e göre piyasa ekonomisi yatırımcıyı tüm toplumun refahı doğrultusunda sevk eden bir düzendir (Böhm, 2008:312).

\section{SONUÇ}

Freiburg Okulu Ordo-liberalizmin temsilcisi olarak değerlendirilmekte ve yaklaşımları liberalizme ve Neo-liberalizme yakın bulunmaktadır. Freiburg Okulu Almanya'daki kartel ve hukuksuzluk sorunlarına karşı görüşlerle şekillenmiş düşünsel bir yapıya hizmet etmektedir. Bu doğrultuda okulun temel görüşü ekonomik anayasanın olması gerekliliği yönündedir. Almanya'nın kurumsal yapılanması önemli ölçüde Freiburg Okulu'na ve bu okulun temsilcilerinden biri olan Böhm'e dayanmaktadır. Böhm hukuk ve ekonomi biliminin bağdaştırılmasını amaçlayan ilk bilim insanlarından biridir. Böhm, liberal piyasa ekonomisinin suni bir yapı olduğunu ve eğer regülasyona tabi tutulmazsa, kendini ortadan kaldırmaya eğilimli olduğunu savunur. Regülasyona tabi olmayan piyasa gücü elinde bulunduran aktörlerin kontrolü altına girecektir. Bu doğrultuda özel hukuk kavramı önem kazanır. Özel hukuk piyasa sürecinin işlerliğini sağlayan kurallar bütünüdür. Bu kurallar iktisadi ve sosyal öngörülebilirliği arttırarak bireylerin hem birbirlerine hem de sisteme güvenmelerini sağlamaktadır. $\mathrm{Bu}$ açıdan özel hukuk kuralları kurumsal yapının nüvesi niteliğindedir. Bu kurumsal yapı demokratikleşme

\footnotetext{
${ }^{40}$ Neoliberallere göre monopollerin millileştirilerek devlet idaresine alınması egemenlik ve bunun suistismali problemini çözmemektedir.
} 
önündeki birçok sorunu ortadan kaldırmaktadır. Rekabet düzeni ise, özgür insanları koordine etme düşüncesiyle demokratik devlet düzeni için adeta mükemmel bir alt yapı olarak hizmet etmektedir.

Böhm'ün piyasa sürecinde bakışı ise piyasanın karşı konulmaz bir kader olduğu (bırakınızyapsınlar) ne de karşı çıkılması gereken bir sonuç (sosyalizm) olduğu yönündedir. $\mathrm{Bu}$ doğrultuda Böhm'ün entegre edici bakış açısına dayanan Ordo-kapitalist pozisyon, belirgin bir şekilde eşitleyici ve nötr bir tutuma dayanmaktadır. Böhm'ün düzen tasavvurunun önkoşulu, her türlü toplumsal baskıdan uzak ve kuvvetli devletin varlığına bağlıdır. Devletin etkin olduğu alan piyasa ekonomisi düzeninin gerekleri tarafından belirlenmeli ve sınırlandırılmalıdır. Bu açıdan Böhm, doğrudan rekabetin doğal olmadığını; ancak hukuki işlerlikle birlikte doğallık kazandığını savunmaktadır. Sadece böyle bir piyasanın varlığının verimlilik artışına yol açacağını savunan Böhm iktisadı hukuki zeminden ayrı görmemiştir.

\section{KAYNAKÇA}

Armack,M.,A.(1976) “'Wirtschaftsordnung und Wirtschaftspolitik”, Studienınd Konzeptezursozialen Marktwirtschaft und zureuropaischen Integratıon, Bern.

Arnauld, A. von (2003a) "Vom Spielvertrag, in: Ders. (Hrsg.), RechtundSpielregeln”, Tübingen: Mohr Siebeck. 51-56.

Böhm,F. Eucken,W. und Doerth,H.G. (1937) "Unsere Aufgabe (Geleitwort der Herausgeber zur Schriftenreihe Ordnung der Wirtschaft)", in: Franz Böhm, Die Ordnung der Wirtschaft als geschichtliche Aufgabe und rechtsschöpferische Leistung. Nebst Einleitung der Herausgeber (= Ordnung der Wirtschaft, Heft 1), Stuttgart, Berlin: Kohlhammer, 7-21.

Böhm, F. (1933) “'Wettbewerb und Monopolkampf”, Berlin. Nachdruck, Köln.

Böhm,F.(1946/1960) "Die Bedeutung der Wirtschaftsordnung für die politische Verfassung", wiederabgedruckt in: Franz Böhm. Reden und Schriften über die Ordnung einer freien Gesellschaft, einer freien Wirtschaft und über die Wiedergutmachung. Herausgegeben von ErnstJoachim Mestmäcker, Karlsruhe: C. F. Müller 46-4850.

Böhm, F.(1960a) “Das Problem der privaten Macht in Böhm”, 25-45 (Erstveröffentlichung in DieJustiz, Bd. III, 1927/28, 324-345).

Böhm, F. (1960b) “DieBedeutung der Wirtschaftsordnungfürdiepolitische Verfassung”, in Böhm 1960: 46-68.

Böhm,F. (1961) "Demokratie und Okonomische Macht, in Kartelle und Monopole im modernen Recht, Beiträgezur Internationalen Kartellrechts-Konferenz”, in Frankfurt a.M.,Juni 1960, Karlsruhe: C.F. Müller, 1-24. 
Böhm,F.(1980) "Freiheitund Ordnung in der Marktwirtschaft, Wirtschaftsrechtund Wirtschaftspolitik" Bd. 60, hrsg. vonErnst-JoachimMestmäcker, Baden Baden: Nomos, 11-212.

Böhm,F.(1980a) “Wirtschaftsordnungund Staatsverfassung”, in Böhm, 53-103.

Böhm,F. (1980b) "Privatrechtsgesellschaf tund Marktwirtschaft", in Böhm 1980, 105-168 Erstveröffentlichung in ord, Bd. 17: 75-151.

Böhm, F. (1980c) “Freiheit und Ordnung in der Marktwirtschaft”, in Böhm.S. 195-209.

Böhm, F. (2008) “Freiheit und Ordnung in der Marktwirtschaft”, in: N. Goldschmidt u. M. Wohlgemuth (Hrsg.), Grundtextezur Freiburger Tradition der Ordnungsökonomik, J.C.B. Mohr (Paul Siebeck), Tübingen, 299-320.

Buchstab, G.(1990) “'Verfolgung und Widerstand”, 1933 - 1945, Düsseldorf.

Eren, Ahmet A. (2015) “Kendiliğinden Düzende Bilgi Diyalektiği: Friedrich August von Hayek”, Ekonomik Yaklaşım, 26 (94): 27-55.

Eucken, W. (1949) “Von der alten zur neuen Wirtschaftspolitik”, Frankfurter Allgemeine Zeitung vom 31. Dezember 11.

Eucken, W. (1951) “'This Unsuccessful Age or The Pains of Economic Progress”, with an Introduction by John Jewkes, London, Edinburgh, Glasgow.

Eucken,W.(1990) “'Grundsätze der Wirtschaftspolitik”, 6. Aufl.,Tübingen: J.C.B. Mohr (Paul Siebeck).

Foucault, M. (2004/I) “'Geschichte der Gouvernementalität I. Sicherheit, Territorium”, Bevölkerung, Frankfurt a.M.:Suhrkamp.

Foucault, Michel (2004/II) "Geschichte der Gouvernementalität II. DieGeburt der Biopolitik", Frankfurt a.M: Suhrkamp.

Böhm, F. (1966) “'Großmann-Doerth, Hans. In: Neue Deutsche Biographie (NDB)', Band 7, Duncker \& Humblot, Berlin, ISBN 3-428-00188-5: 155.

Gerber, D. J. (1994) "Constitutionalizing the Economy: German Neoliberalism, Competition Lawand the ,New' Europe", The American Journal of Comparative Law 42: 25-84.

Goldschmidt, N.Rauchenschwandtner,H. (2007) “The Philosophy of Social Market Economy: Michel Foucaultś Analysis of Ordoliberalism", 20. cilt/Freiburger Diskussionspapierezur Ordnungs ökonomik Inst. für Allg. Wirtschaftsforschung, Abt. für Wirtschaftspolitik, 17-30.

Grossekettler,H.(1997) “'Die Wirtschaftsordnung als Gestaltungsaufgabe’, Entstehungsgeschichte und Entwicklungs perspektivendes Ordoliberalismus nach 50 Jahren Sozialer Marktwirtschaft, Münster/Hamburg. 
Grossekettler, H. (1999) "Kritik der Sozialen Marktwirtschaftaus der Perspektive der Neuen Institutionen ökonomik", in: K.W. Nörrund J. Starbatty, Hrsg.,SollundHaben - 50 Jahre Soziale Marktwirtschaft, Stuttgart: Lucius\&Lucius, 53-81.

Hansen, N.(2009) “'Franz Böhm mit RicardaHuch - zweiwahrePatrioten”, Düsseldorf.

Hayek, F. A. (1983) “Die Wiederentdeckung der Freiheit” - Persönliche Errinerungen, Köln, 9- 12.

Hegner,J.(2000) “Alexander Rüstow Ordnungspolitische Konzeptionund Einflussaufdaswirtschaftspolitische Leitbild der Nachkriegszeit in der Bundesrepublik Deutschland', Stuttgart: Lucius\&Lucius.

Hobbes,T. LeviathanortheMatter, FormeandPower of an Common-Wealth Ecclesiasctical and Civill., London 1651.

Hollerbach,A. (2007) “Wissenschaft und Politik : Streiflichterzu Leben und Werk Franz Böhms” (1895-1977) / Sonderdruckeaus der Albert-Ludwigs-UniversitätFreiburg. 280-299.

Janssen,H. (2000) “Nationalökonomie und Nationalsozialismus”, Die deutsche Volkswirtschaftslehre in den dreißiger Jahren, 2. Aufl., Marburg: Metropolis.

Ladeur, Karl-Heinz 2004 "Kritik der Abwägung in der Grundrechtsdogmatik”, Bd. 170 der BeiträgezurOrdnungstheorieundOrdnungspolitik, Tübingen: MohrSiebeck.

Mestmäcker, E.J. (1995) “Wirtschaftsordnung und Geschichtsgesetz", in: Wirtschaftsordnungals Aufgabe, zum 100. Geburtstagvon Franz Böhm, Ludwig-Erhard-Stiftung, Krefeld: Sinus-Verlag, 111-136.

Miksch, L. (1947) “'Wettbewerbals Aufgabe”, Godesberg: Verlag Helmut Küpper.

Nils, G. (2005) "Wirtschaft, Politik und Freiheit", Freiburger Wirtschaftswissenschaftler und der Widerstand', Hrsg. v. Untersuchungenzur Ordnungstheorieund Ordnungspolitik 48 Walter EuckenInstitut. MohrSiebeck.

Norr, K. (1994a) “Die Leidendes Privatrechts - Kartelle in Deutschlandvon der Holzstoffkartellentscheidung zum Gesetzgegen Wettbewerbsbeschränkungen, Tübingen: J.C.B. Mohr (Paul Siebeck).

Oswalt, W. (2007) "Vorwort", in: T. Roser u. W. Oswalt (Hrsg.), Entmachtungdurch Wettbewerb, Walter Eucken Archiv, LIT Verlag Dr. W. Hopf, Berlin, 7 - 13.

Reinhard,R.(1969) “Soziale Marktwirtschaft”, Wirtschaftspolitik zwischen Neoliberalismus, Tübingen.

Ritter, G.(1954-1955) “Carl Goerdelerunddiedeutsche Widerstandsbewegung”, Stuttgart. 
Saving,F.C.von(1814) "Vom Berufunzerer Zeitfür Gesetzgebung und Rechtswissenschaft', Heidelberg.

Schmölders, Günter, DasMoralische in der Politik, Würdigung Franz Böhmszudess en 75. Geburtstag, FrankfurterAllgemeineZeitung, 14 Şubat 1970.

Smith, A.(1926) “'Die Theorieethischer Gefühle, Bd. II, hrsg. VonWalterEckstein, Hamburg.

Vanberg, V. J. (1994a) "Rules and Choice in Economics", Londonund New York: Routledge.

Vanberg,V.J. (2005) “Market and State: the Perspective of Constitutional Political Economy", Journal of Institutional Economics 1: 23-49.

Vanberg,V.J.(2002) "Constitutional Economics and Ethics - on the Relation between SelfInterestand Morality”, in: Brennan, Geoffrey, HartmutKliemt, Robert D. Tollison (Hrsg.), MethodsandMorals in ConstitutionalEconomics - Essays in Honor of James M. Buchanan, Berlin, Heidelberg: SpringerVerlag, 485- 503.

Wetzel, M. J. (1987) "Limnodrilustortilipenis, a new North Americanspecies of Fresh Watertubificidae (Annelida: Clitellata: Oligochaeta)", Proceedings of theBiologicalSociety of Washington. 100(1): 182-185, Washington. 